\title{
PERFORMANCE OF ECCENTRICALLY BRACED FRAMES UNDER THE ACTION OF LATERAL LOAD
}

\author{
Ramya A ${ }^{1}$, Muthumani $K^{2}$, Nafeez Ahmed $\mathbf{L}^{3}$ \\ ${ }^{I}$ M.Tech (Structural Engineering), School of Mechanical and Building Sciences, VIT University Chennai Campus, \\ Chennai-600127, Tamil Nadu, India, ramya.a2014@vit.ac.in \\ ${ }^{2}$ Professor, School of Mechanical and Building Sciences, VIT University Chennai Campus, Chennai-600127, Tamil \\ Nadu, India, muthumani.k@vit.ac.in \\ ${ }^{3}$ Asst Professor, Department of Mechanical Engineering, Gojan School of Business and Technology, Chennai- \\ 600052, Tamil Nadu, India, nafeez1588@gmail.com
}

\begin{abstract}
Synopsis
Steel moment resisting frames experiences large lateral displacements during severe earthquake ground motions and require special attention to control lateral displacement and to limit the damage to nonstructural elements. Engineers started providing concentric braces to steel moment resisting frames to control the lateral displacement. It was observed in few earthquakes (Mexico 1985, Loma Prieta 1989, Northridge 1995) that such concentrically braced steel moment resisting frames did not perform well. The most severe damage was observed in frames where braces were proportioned to resist tension only, where connections were weaker than the braces attached to them, where braces framed into columns and where braces were inclined principally in one direction. The concept of incorporating braces eccentrically attracted the interest of researchers and the seismic performance seems to improve. This paper attempts to study the seismic performance of steel moment resisting frames with eccentric braces. The study concern with the enhancement of seismic performance by accomplishing eccentrically braced frames during undesirable earthquakes. Three steel framed structures (6 storey, 9 storey and 15 storey) are designed for the lateral force and their final performances of structure are evaluated through linear analysis using ETABS 2015 V.15.
\end{abstract}

Key words: steel moment resisting frame, eccentric brace, seismic performance, lateral displacement $* * *$

\section{INTRODUCTION}

An eccentrically braced frame (EBF) is normally used in steel moment resisting frames to enhance the seismic performance. When such a frame is subjected to a severe seismic event, large axial force and bending moments are produced in the beam outside of the link [1].In general, under the design basis earthquake EBF are recognized to be remain elastic. In past two decades braced frames are commonly used in steel buildings in the region of high seismic risk zones to preventive from vulnerable seismic damages to the structures. The braced frames provides efficient lateral stiffness and strength and supplemental performance also being taken care by the links, which undergo inelastic deformations and this become the essential source of energy dissipation. Experimental evaluation was reported from the University of California at Berkeley and the National Taiwan University which stated that limited yielding outside the link may not cause any severe effects on EBF behavior. The comprehensive assessment study was conducted by Chen and Mahin [2] on performance based seismic demand of 2-, 3-, 5-, and 16- story special concentrically frames that were designed based on ASCE705[3]. Therefore, a few major concerns about the current practice in designing this EBF earthquake resistant steel structure are as follows,

(1) How such an inelastic deformation affects the seismic behavior of the whole frame.
(2) Unfortunate inelastic deformation in intersected beams would influence the overall seismic response of the frame.

(3) What are the actual mechanisms in an eccentrically braced frame.

In order to address these questions an attempt is made to study the seismic performance of concentric and eccentric bracing system on a steel moment resisting frame.

\section{LITERATURE REVIEW}

Gul Yigitsoy et al reported that the stability of beams in steel eccentrically braced frames when subjected to severe seismic event introduced large axial force and bending moment in the beam outside the link [1]. It is formed that controlled yielding in the beams is not detrimental to EBF performance as long as stability of beam is maintained. A total of $51 \mathrm{EBF}$ sub assemblage models were analyzed in the computational study carried out by them which did not satisfy capacity based design requirements. The results indicate that the link overstrength factor should be a function of link length for performing capacity based design of beam outside of the link. This is because flexure yielding links, which are problematic to beam stability, tend to develop smaller over strength compared to shear yielding link.

Chen C-H, Mahin SA (2012) performed evaluation of seismic design parameters for 2,3,6,12 and 16 storey steel braced frames which demonstrated that short period braced 
frame system had higher probabilities of collapse than longer period braced framed system.

Jay Shen et al in their paper reported the study of braced intersected beams in two-storey X-braced frames. They did dynamic analysis to determine the actual mechanisms and impact of a yielding beam on non structural components such as braces and connections. As a results yielding of such brace-intersected frames further increases inelastic deformation of the beam. Vertical inelastic displacement at the mid span of beam causes predominant ductility demand on braces, gusset plates and beam to column connections are not involved in current design practice. This was found helpful in the redistribution of the total input energy demand.

Gary S et al studied the performance and economy aspects of EBF. Eccentric braced frames have few limitations such as links to column connections are required so to counteract this effect of eccentric braced frames. The analytical study was carried out, as the results are obtained from the non linear time history analyses which indicate residual drifts in EBF.

\section{Seismic study on SMRF}

a. Selection of structures

A typical office building with 6,9 and 15 stories respectively as shown in Figs. 1 and 2 are selected for the study. The study involves special concentrically braced frame (SCBF), eccentrically braced frames (EBF) incorporating with chevron braces in alternating stories. To resist seismic force bracings in both orthogonal directions are arranged on the perimeter of the building. The floor system consists of a $120 \mathrm{~mm}$ thick concrete slab cast in situ place concrete. Dead and live loads of $4 \mathrm{kN} / \mathrm{m}^{2}$ and $2.50 \mathrm{kN} / \mathrm{m}^{2}$ respectively were considered in the design. It is assumed to locate the buildings at hard soil category and falls under the category of zone -IV as per IS 1893-2002.

b. Structural model of the frames parameters

The three buildings symmetric plan dimensions of $47.5 \mathrm{mx} 47.5 \mathrm{~m}$ with storey height of $3.5 \mathrm{~m}$ are to be considered in the design and evaluation. The structure has 5 bays at $9.5 \mathrm{~m}$ in each direction of buildings. Seismic weights for the 6-, 9-, and 15- storey buildings as computed as per IS $1893-2002$ are $107539.131 \mathrm{kN}, 235890 \mathrm{KN}$ and 628916.751 $\mathrm{kN}$ respectively. The beams and columns are steel wide flange sections with specific yielding strength, $F_{Y}=250$ $\mathrm{MPa}$ and the braces of steel angle sections are chosen.

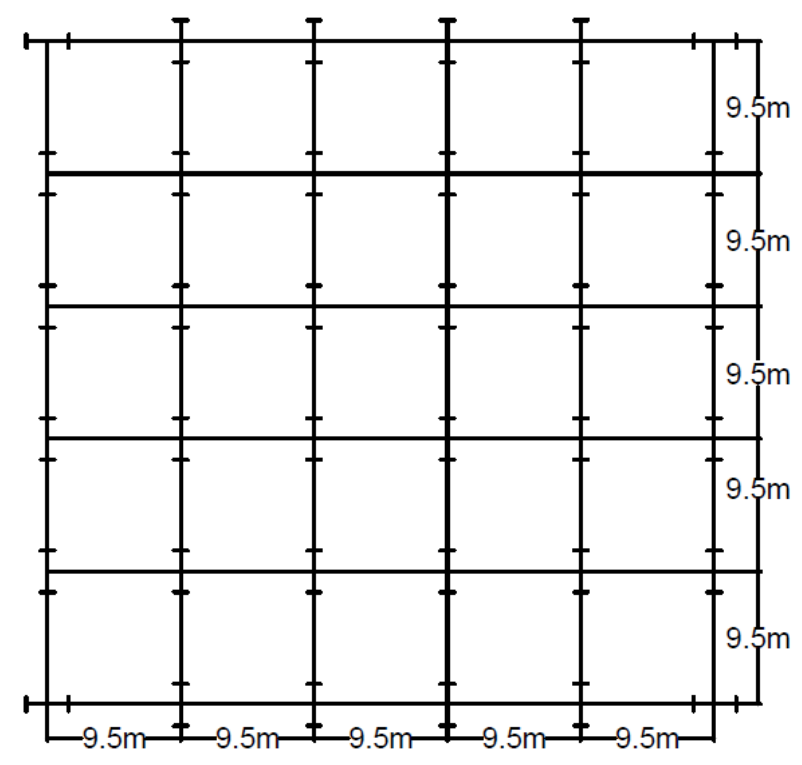

Fig. 1 Plan of the building

\section{Merits Of Bracing System In A Structure}

The performances of steel framed structure are considered to be excellent when it is subjected to seismic loading due the ductility of materials and members. Braced frames are most efficient structural systems in steel construction because these provide complete truss action.

\section{Seismic performance of braced system}

a. Modelling and analysis

The seismic performance was evaluated by linear analysis using ETABS 2015 V.15 software. Beams and columns are modelled as standard frame elements. Then the braced frames of SCBF and EBF elements are chosen with respect to Indian standard angle section. Frame properties of column ISHB 450, beam ISMB 400 and ISMB 225 are chosen respectively for modelling and design. Similar configuration is used for 9 and 15 storey structure also.

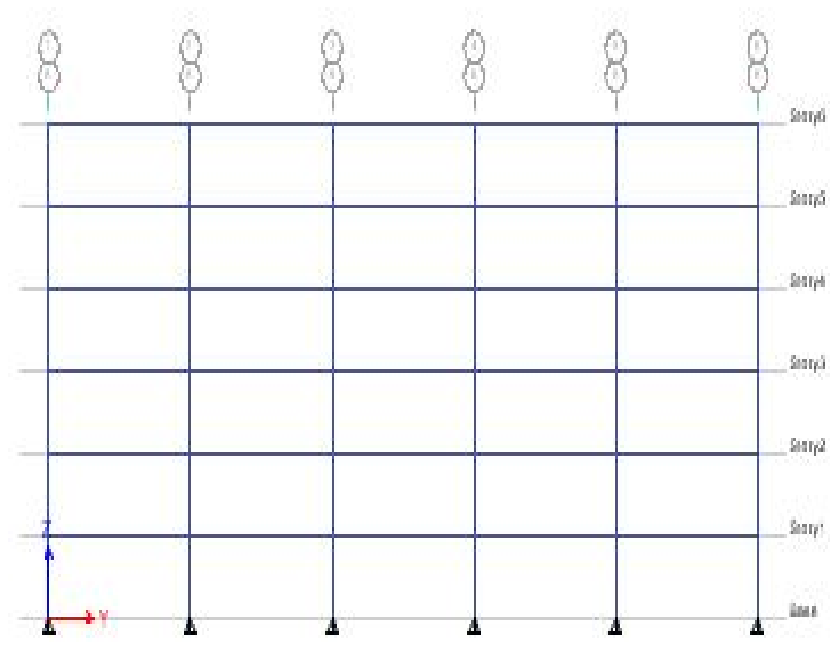

Fig.2. 6 storey plane frame 


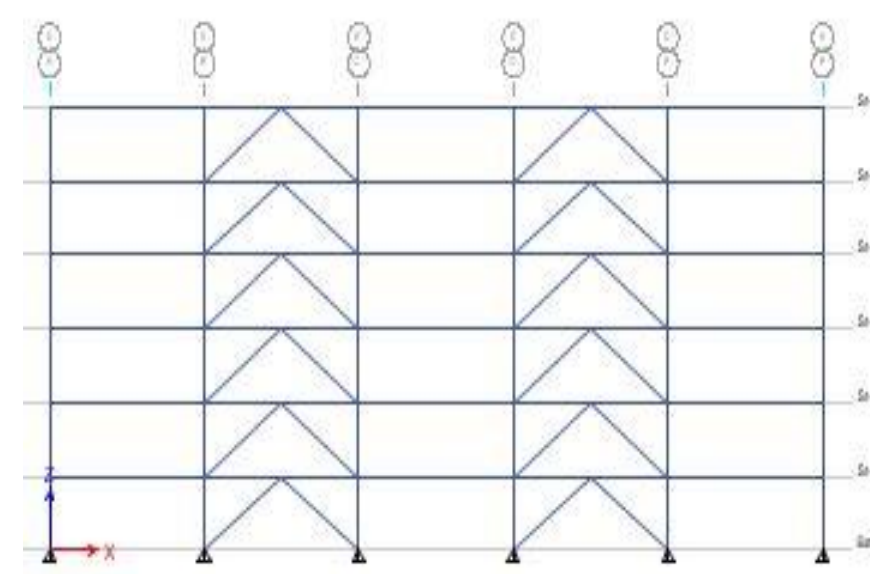

Fig.3. 6 storey Concentric braced frame

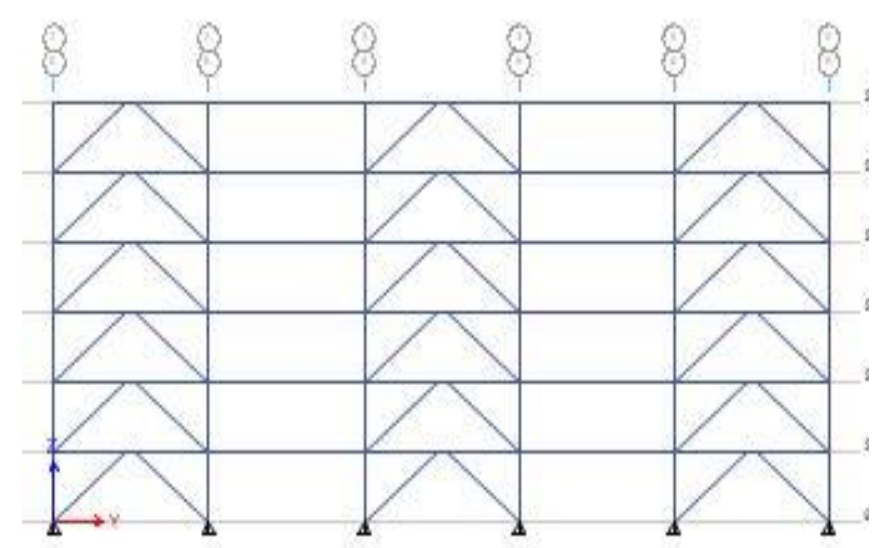

Fig.4. 6 storey eccentric braced frame

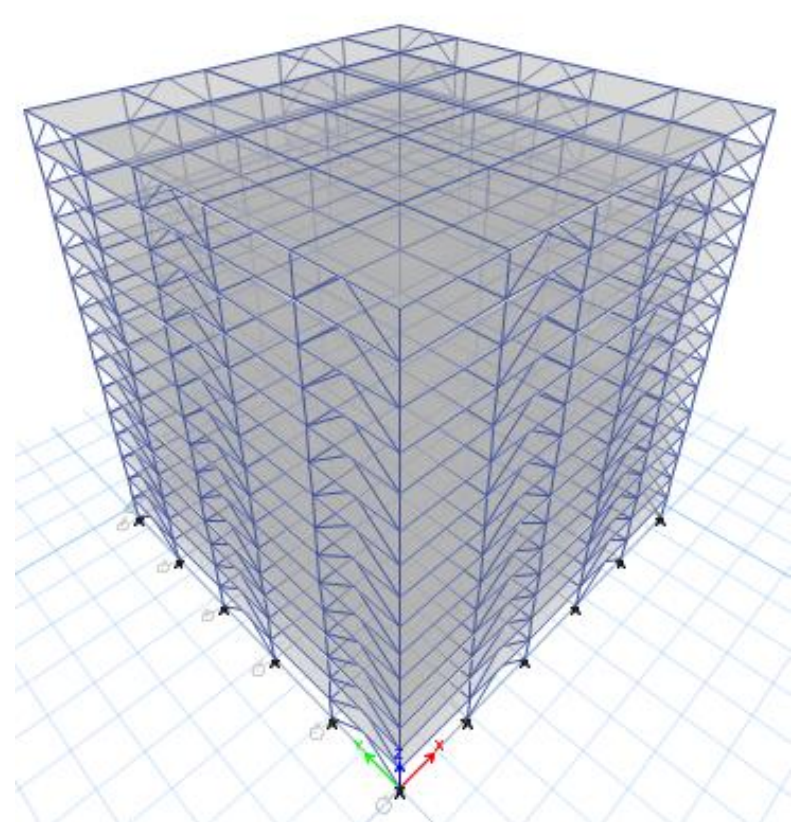

Fig.5. 3D view of the building 
Table 1-6 storey lateral load distribution as per IS 1893-2002

\begin{tabular}{ccccc}
\hline $\begin{array}{c}\text { Storey } \\
\text { Level }\end{array}$ & $\begin{array}{c}\text { Height } \\
\text { in } \mathbf{~ m m}\end{array}$ & $\begin{array}{c}\text { Plane } \\
\text { frame }\end{array}$ & $\begin{array}{c}\text { Concentric } \\
\text { braced frame }\end{array}$ & $\begin{array}{c}\text { Eccentric } \\
\text { braced frame }\end{array}$ \\
\hline 6 & 2100 & 2240.90 & 2489.88 & 2240.897 \\
5 & 1750 & 1913.12 & 2125.69 & 1913.118 \\
4 & 1400 & 1255.30 & 1361.44 & 1225.299 \\
3 & 1050 & 689.11 & 765.678 & 306.109 \\
2 & 750 & 306.48 & 340.540 & 766 \\
1 & 350 & 76.13 & 84.59 & 737 \\
\hline
\end{tabular}

Table 2-9 storey lateral load distribution as per IS 1893-2002

\begin{tabular}{|c|c|c|c|c|}
\hline $\begin{array}{c}\text { Storey } \\
\text { Level }\end{array}$ & $\begin{array}{l}\text { Height } \\
\text { in } \mathbf{~ m m}\end{array}$ & $\begin{array}{l}\text { Plane } \\
\text { frame }\end{array}$ & $\begin{array}{c}\text { Concentric } \\
\text { braced frame }\end{array}$ & $\begin{array}{c}\text { Eccentric } \\
\text { braced frame }\end{array}$ \\
\hline 9 & 3150 & 4710.08 & 4186.745 & 3766.778 \\
\hline 8 & 2800 & 3917.33 & 3482.076 & 3132.794 \\
\hline 7 & 2450 & 2999.05 & 2665.821 & 2398.416 \\
\hline 6 & 2100 & 2202.85 & 1958.094 & 1761.681 \\
\hline 5 & 1750 & 1528.76 & 1358.896 & 1222.587 \\
\hline 4 & 1400 & 978.47 & 869.754 & 782.511 \\
\hline 3 & 1050 & 550.28 & 489.141 & 440.076 \\
\hline 2 & 750 & 244.19 & 217.056 & 195.283 \\
\hline 1 & 350 & 61.21 & 54.407 & 48.9502 \\
\hline Total & & 17192.22 & 15281.99 & 13749.08 \\
\hline
\end{tabular}

Table 3-15 storey lateral load distribution as per IS 1893-2002

\begin{tabular}{ccccc}
\hline $\begin{array}{c}\text { Storey } \\
\text { Level }\end{array}$ & $\begin{array}{c}\text { Height } \\
\text { in mm }\end{array}$ & $\begin{array}{c}\text { Plane } \\
\text { frame }\end{array}$ & $\begin{array}{c}\text { Concentric } \\
\text { braced frame }\end{array}$ & $\begin{array}{c}\text { Eccentric } \\
\text { braced frame }\end{array}$ \\
\hline 15 & 5250 & 4771.16 & 4236.182 & 3810.380 \\
14 & 4900 & 4383.64 & 3892.114 & 3500.896 \\
13 & 4550 & 3779.00 & 3355.271 & 2572.445 \\
12 & 4200 & 3221.09 & 2859.911 & 2161.99 \\
11 & 3850 & 2707.14 & 2403.593 & 1786.664 \\
10 & 3500 & 2237.17 & 1986.320 & 1446.451
\end{tabular}




\begin{tabular}{lrrrr}
\hline 8 & 2800 & 1431.89 & 1271.342 & 1143.553 \\
7 & 2450 & 1093.85 & 971.198 & 873.577 \\
6 & 2100 & 805.27 & 714.977 & 643.111 \\
5 & 1750 & 557.92 & 495.359 & 445.568 \\
4 & 1400 & 357.29 & 317.225 & 285.339 \\
3 & 1050 & 201.34 & 178.768 & 160.799 \\
2 & 750 & 89.51 & 79.477 & 71.4885 \\
1 & 350 & 22.38 & 19.868 & 17.871 \\
\hline Total & & & $\mathbf{2 1 3 9 8 . 1 5}$ \\
\hline
\end{tabular}

Tables 1 to 3 gives the lateral loads due to earthquake as computed using IS 1893-2002 for the three structures considered. The addition of bracing is likely to make the structure stiffer and hence the period is likely to come down from the values computed from the code given expression. In case of six and nine storey structures $\mathrm{S}_{\mathrm{a}} / \mathrm{g}$ value is the maximum and hence the lateral force is not likely to change for the lower period. But in case of fifteen storey structure the $S_{a} / g$ value is found to be 1.458 which is likely to go up if the natural period from dynamic analysis is used. However in this paper the time period is computed as per IS 18932002 and the results are compared.

\section{ANALYSIS RESULTS AND CONCLUSIONS}

The seismic performance of 6 storey, 9 storey and 15 storey structure incorporated with specially concentrated braced frame $(\mathrm{SCBF})$ and eccentric braced frame (EBF) are evaluated by linear analyses. The seismic performance is evaluated in terms of maximum storey displacement, storey drift ratio. This paper plans to assess the performance level of structure without bracing, with incorporating brace SCBF and EBF in alternative bays respectively. Mainly bracing which governs the seismic load (i.e. lateral action), so that the beam column connections were assumed to be pinned connection.

The results of this study can be summarized as follows

(1) It has been observed that the performances of building 6 storeys, 9 storeys and 15 storeys without bracing system were subjected to lateral load results in higher maximum storey displacement.

(2) To control the effect of such maximum storey displacement, specially concentrated braced frames are incorporated in alternative bays to achieve the functional requirement under the seismic loads which results in the better than the structure without bracing system.

(3) Further to enhance the structural integrity and resistance with respect to lateral loads, eccentric braced frames were incorporated to target the lesser maximum storey displacement compared to the conventional braced system.

(4) From the study it has been observed that the number of bracing bays and height of building have greater effect on the performance.

The following graphs are plotted storey height with displacement results of this study are enlisted below

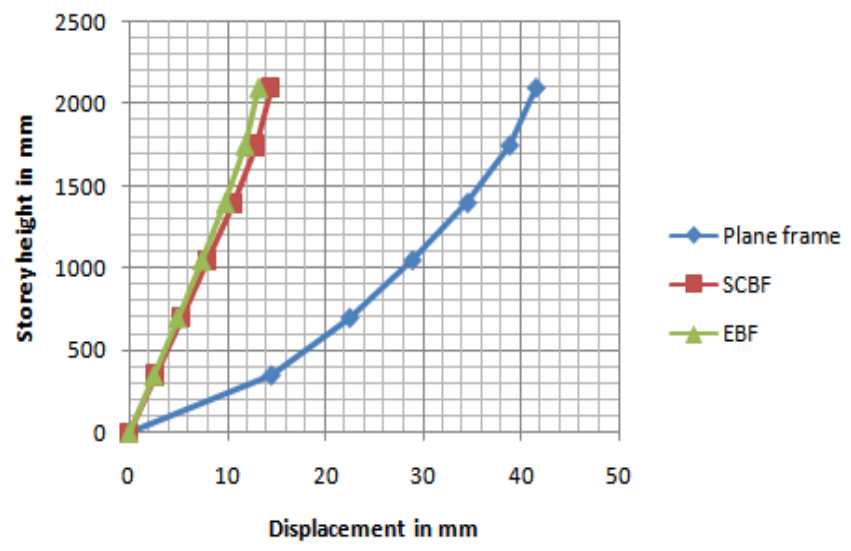

Fig .6. 6 storey Maximum displacement

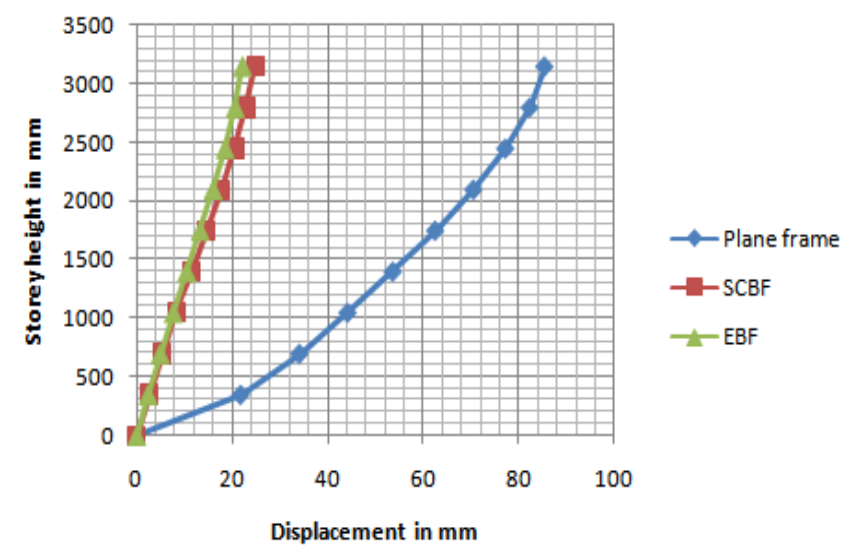

Fig.7. 9 storey maximum displacement 


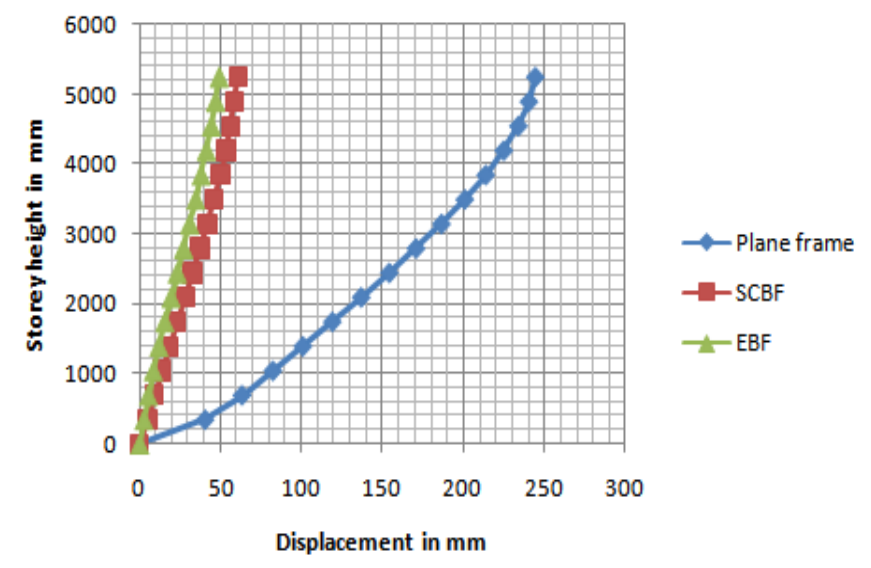

Fig.8. 15 storey maximum displacement

\section{REFERENCES}

[1] Gul Yigitsoy, Cem Topkaya, Taichiro Okazaki., "Stability of beams in steel eccentrically braced frames", Journal of Constructional Steel Research., vol (96)-May2014, CD01 pp14-25.

[2] Chen C-H, Mahin SA., "Performance Based Seismic Demand Assessment of concentrically Braced Steel Frame Buildings", PEER Report 2012/103, University of California, Berkeley, Dec2012.

[3] ASCE 7-05. Minimum Design loads for buildings and other structures, ASCE 7-05. Viriginia: American society of civil Engineers; 2005.

[4] Mussa Mahmoudi, Mahdi zaree, "Evaluating response modification factors of concentrically braced frames", Journal of Constructional Steel Research 66 (2010) 1196-1204.

[5] Moghaddam H, Hajirasouliha I, Doostan A. "Optimum seismic design of concentrically braced steel frames", concepts and design procedures. Journal of Constructional Steel Research 2005; 61(2):151-66.

[6] Sabelli R., "Research on improving the design and analysis of earthquake resistant steel braced frames". Final report NEHRP Fellowship in Earthquake Hazard Reduction; 2000.

[7] Federal Emergency Management Agency. FEMA. "Next-generation performance-based seismic design guidelines program plan for new and existing buildings", FEMA-445. Washington (DC); 2006.

[8] Housner G., "Limit design of structures to resist earthquakes", In: Proceedings of the first world conference on earthquake engineering. 1956.

[9] Lee SS, Goel SC., "Performance-based design of steel moment frames using target drift and yield mechanism", Report no. UMCEE 01-17; MI: University of Michigan at Ann Arbor; 2001.

[10] Chao SH, Goel SC., "Performance-based design of eccentrically braced frames using target drift and yield mechanism", AISC Eng J 2006; 173_200. 3rd Quarter.

[11] Chao SH, Goel SC., "Performance-based plastic design of special truss moment frames", AISC Eng J 2008; 127_50.2nd Quarter.

[12] Goel SC, Chao SH., "Performance-based plastic design earthquake resistant steel structures", International Code Council; 2008. p. 261.
[13] Chao SH, Goel SC, Lee SS., "A seismic design lateral force distribution based on inelastic state of structures", Earth Spectra 2007; 23(5):547_69.

[14] AISC., ANSI/AISC 341-05. "Seismic provisions for structural steel buildings".

[15] Gupta A, Krawinkler H., "Prediction of seismic demands for SMRFs with ductile connections and elements", Report no. SAC/BD-99/06. Sacramento (CA): SAC Joint Venture; 1999.

[16] Building Seismic Safety Council. BSSC, "National earthquake hazard reduction program (NEHRP) recommended provisions for seismic regulations for new buildings and other structures part 2: commentary", FEMA 450-1.

[17] Richards PW., "Seismic column demand in ductile braced frames", Journal of Structural Engineering 2009; 135(1):33_41.

[18] Thornton W, Muir LS. Design of vertical bracing connections for high-seismic drift. Modern Steel Construction; March 2009.

[19] Malley JO, Popov EP, Shear links in eccentrically braced frames. Journal of structural Engineering 1984; 110(9):2275-95.

[20] Engelhardt MD, Tsai KC, Popov EP, "Stability of beams in eccentrically braced frames", In: Fukumoto, Lee, editors. Stability and ductility of steel structures; 1992.p.99-112. 